\title{
TRT Yayınlarının Hukukî Denetimi: Geçmişten Günümüze Bir İnceleme
}

\author{
Legal Control of TRT Broadcasts: A Review from the Past to the Present
}

Kemal Cem Baykal, Dr. Öğr. Üyesi, Çanakkale Onsekiz Mart Üniversitesi İletişim Fakültesi, E-posta: kcbaykal@comu.edu.tr

https://doi.org/10.47998/ikad.988382

Anahtar Kelimeler:

TRT,

RTÜK,

Denetim,

İdarî denetim,

Yayıncılık.
$\ddot{\mathbf{O z}}$

Radyo ve televizyon kuruluşları özgür olmalı, ancak bu özgürlüklerini kötüye kullanmamaları için katı olmayan bir hukukî denetime tâbi olmalıdır. Bu durum, özellikle liberal öğretinin bir uzantısı olan 'Toplumsal Sorumluluk Teorisi'nin bir ilkesidir. Çalışma kapsamında betimleyici araştırma tekniği uygulanarak, kuruluşundan günümüze Türkiye Radyo ve Televizyon Kurumu (TRT) üzerindeki hukukî denetim yapısı ortaya konulmaya çalıșılmıştır. Elde edilen bulgular neticesinde, TRT'de hukukî denetim türlerinden 'idarî denetim'e başvurulduğu görülmüştür. Merkezî yayın denetimi, kurum içi hiyerarşik denetim şeklinde 1966 yılında başlamıştır. 1983 yılında 2954 sayılı Kanun'un yürürlüğe girmesiyle, kurum içi hiyerarşik denetime yeni bir katman eklenmiş ve TRT'ye ilk kez bir dış idarî denetleyici kurum tayin edilmiştir. Ancak bu kurumun yetkilerinin sınırlı olması nedeniyle, bu dönemde de TRT yayınlarının denetiminde önceki döneme nazaran büyük bir kırılma yaşanmamıştır. Asıl ciddi kırılma, özel yayıncılığın başlaması ile 1994 yılında RTÜK'ün kurulması sonrasında gerçekleşmiştir. TRT, kendi kurum içi hiyerarşik denetimine ek olarak, bağımsız bir idarî otorite konumunda bulunan RTÜK denetimine tâbi tutulmuştur. 2002 yılında bu uygulamadan vazgeçilmiş olsa da, 2011 yılında TRT yayınları yeniden RTÜK tarafından denetlenmeye başlamıştır. Bu durumun yol açtığı en önemli sorun; 1994 yılından itibaren özel yayıncılar ile TRT'ye farklı yaptırımlar uygulanması ve yayıncılık alanının farklı aktörleri arasında eşitsizliğin ortaya çıkmasıdır.

Keywords:

TRT,

RTUK,

Control,

Administrative

Control,

Broadcasting.

\section{Abstract}

Radio and television organizations should be free. However, they must be subject to reasonable legal control so that they do not abuse their freedom. This is a principle of the Social Responsibility Theory, which is an extension of liberal doctrine. In this study, descriptive research technique was applied, and it has been tried to reveal the legal control structure on the Turkish Radio and Television Corporation (TRT) since its establishment. As a result of the findings, it was seen that 'administrative control', one of the legal control types, was used in TRT. The control of broadcasts began in 1966 in the form of internal hierarchical control. With the enactment of Law No. 2954 in 1983, a new stage was added to the internal hierarchical audit. In addition, an external administrative supervisory body was appointed to TRT for the first time. However, due to the limited powers of this body, there has not been much change in the structure of the control. The main transformation took place with the establishment of RTÜK in 1994, with the start of private broadcasting. In addition to its own internal hierarchical control, TRT was subject to the control of RTÜK, which is an independent regulatory agency. The most important problem caused by this situation is that different sanctions are imposed on private broadcasters and TRT since 1994. Therefore, the equality between the different actors of the broadcasting field disappears. 


\section{Giriş}

Türkiye'de radyo yayıncılığı, Batı ülkeleri ile aynı dönemde başlamış olsa da, televizyon yayıncılığı konusunda yaklaşık 30 yıl geç kalınmıştır. Bu durum, yayıncılık açısından birtakım normların, ilke ve esasların yerleşmesi hususunda geç kalınmasına neden olmuştur. Özellikle radyo ve televizyonun ilk yıllarında, bu araçların toplum üzerinde mutlak etkilere sahip olduğu ön kabulü, sıkı bir denetim uygulamasının da yolunu açmıştır.

Radyo ve televizyon yayınlarının toplum üzerinde mutlak etkili olduğu kabulüne yol açan ilk ve belki de en etkili örnek; Türkiye'de de radyo yayınlarının başlamış olduğu bir dönemde, Amerika Birleşik Devletleri'nde (ABD) gerçekleşmiştir. 30 Ekim 1938'de yayınlanan ve oldukça panik yaratan Dünyalar Savaşı (War of the Worlds) uyarlaması, dönemin en ünlüradyo programlarından biridir. Oyun, ikinci perdede dinleyiciler tarafından bir haber bülteni gibi algılanmış, çok sayıda Amerikalı, Marslıların New Jersey’i işgal ettiği haberiyle panik yaşamıştır. Uzaylılar, New Jersey milislerinin çoğunu buharlaştırıp New York'a doğru yürümeye başladığında, heyecan daha da artmış ve dinleyiciler panik içerisinde evlerini terk etmeye başlamışlardır. Olaylar, yayını yapan CBS'in dava edilmesiyle sonuçlanmıştır. Bu örnek, özellikle İkinci Dünya Savaşı öncesinde, dost ve düşman ellerdeki radyonun halka neler yapabileceğini göstermesi bakımından önem arz etmektedir (Hilmes, 2011: 116).

İkinci Dünya Savaşı sonrası dönemde, medyanın etkilerinin 'çok güçlü' olduğu fikri tartışılmaya başlanmıştır. Özellikle Paul Felix Lazarsfeld ve Carl Hovland, 1940'lı ve 1950'li yıllar boyunca “sınırlı etki teorisi”’ni geliştirmişlerdir. Sınırlı etki paradigmasının en önemli yaklaşımlarından olan ve 'medya insanlara ne yapar?' sorusu yerine 'insanlar medya ile ne yapar?' sorusuna odaklanan Kullanımlar ve Doyumlar Yaklaşımı, 1970'lerden başlayarak televizyon ve izleyici ilişkisine odaklanmıştır. Yaklaşım, günümüzde halen canlılığını korumaktadır (bkz. Özçetin, 2019: 104, 113-114).

Son yıllarda, özellikle dijital teknolojilerin televizyonun taşıyıcılığını yaptığı da düşünüldüğünde, Türkiye'de televizyon izleme pratiğinin yaygınlığ $1^{1}$ ve bu yayınların insanları ne yönde etkilediği hususu sıkça tartışılmaktadır. Neticede Türkiye Radyo ve Televizyon Kurumu'nun (TRT) kurulmasından sonra 1966'da başlayan, halen devam eden ve 1994 yılından itibaren özel yayıncıları da kapsar hale gelen yayın denetimleri, yayıncılığın olumsuz etkilerini ortadan kaldırmanın en önemli yolu olarak görülmüş ve halen de görülmeye devam etmektedir. Şüphesiz, siyasal ve teknolojik sebepler de yayıncıların denetlenmesinin diğer nedenleri arasındadır.

Yayınların olumsuz unsurlarını ortadan kaldırmanın yegâne yolunun 'denetim' olup olmadığı hususu tartışmalı olsa da bu çalışmada; kuruluşundan günümüze değin, bir kamu yayın kuruluşu ${ }^{2}$ olan ve Türkiye'de radyo ve televizyon yayıncılığının önemli

1 Radyo ve Televizyon Üst Kurulu'nun 2018 yılında yaptığı bir araştırmaya göre, yüksek düzeyde eğitim sahibi kişiler günde yaklaşı üç saat, düşük düzeyde eğitimliler ise günde dört saat televizyon izlemektedir (www.trthaber. com, 21.11.2020).

2 Kamu hizmeti yayıncılığı, radyo ve televizyon kanallarının özel metalar değil, kamu malları olarak düzenlenmesi anlamına gelmekle birlikte yayınların kamusal enformasyon, kültür-eğitim ve eğlence kaynaklarını geliştirmekle yükümlü ulusal kültür kurumları olarak düzenlenmesi olarak da kabul edilmektedir (Mutlu, 1998: 194). 
yapı taşlarından biri konumunda bulunan TRT yayınlarının tâbî olduğu hukukî denetim yapısını ortaya koymak, açıklamak, problemli yönlerini tespit etmek ve çözüm önerilerinde bulunmak amaçlanmıştır. Bu konuya odaklanılmasının temel nedeni; geçmişten günümüze kadar geçen süreçte TRT yayınlarının denetiminin toplumda çeşitli tartışmalara yol açması ve kimi zaman problemli yönleriyle öne çıkmış olmasıdır. Çalışma, konuya geniş bir perspektiften bakabilmek amacıyla, TRT yayınlarının denetimi bakımından herhangi bir zaman dilimiyle sınırlandırılmamıştır. Ayrıca, geçmişten günümüze TRT yöneticilerinin ve program denetçilerinin almış olduğu tartışmalı kararlar, kamuoyu tepkileri, eleştirilen denetim ve sansür uygulaması örneklerine bu çalışma kapsamında yer verilmemiştir. Zira bu örnekler hem sayıca çok fazladır, hem de daha önce üzerlerinde fazlaca durulmuştur. Dolayısıyla, çalışmanın konusu, TRT yayınlarının hukukî denetim yapısının sistemsel açıdan analiz edilmesiyle sınırlanmıştır.

Çalışmada betimleyici araştırma yöntemi kullanılmıştır. Erdoğan'a göre (2003: 138), 'betimleyici' kavramı, bir durumun, koşulun, insanın, ilişkinin, plânlı faaliyetin, iletişim sürecinin, uygulanan politikanın 'ne olduğunu' tasvir, tarif ve açıklığa kavuşturma anlamına gelmektedir. Söz konusu yöntem çerçevesinde, ilk olarak radyo ve televizyon yayınlarında 'denetim' olgusunun teorik çerçevesi ortaya konulmaya çalışılmıştır. Bu kapsamda öncelikle TRT yayınları üzerindeki hukukî denetim politikaları tarihsel bağlamda ele alınarak her bir hukukî denetim türü açıklanmış, bu denetim türlerinin özellikleri üzerinde durulmuştur. Çalışmanın son kısmında ise; TRT yayınlarının hukukî denetimi, günümüz iletişim politikaları bağlamında ele alınmış, 6112 sayılı Radyo ve Televizyonların Kuruluş ve Yayın Hizmetleri Hakkında Kanun'un (R.G. Tarih: 03.03.2011 / Sayı: 27863) TRT için öngördüğü denetim şartları, özel yayıncılara uygulanan denetim şartları ile mukayese edilmiş, Radyo ve Televizyon Üst Kurulu (RTÜK) tarafindan TRT'ye uygulanan yaptırımlar tespit edilmiş, sorunlar ortaya konulmuş ve neticede çözüm önerilerinde bulunulmuştur. Böylece, TRT yayınları üzerinde kurulan hukukî denetim sistemi hem tarihsel, hem de güncel bir perspektiften ele alınmaya çalışılmıştır.

Çalışmada geniş bir literatür ve mevzuat taramasına başvurulmuş olup, TRT’ye RTÜK tarafindan uygulanan yaptırımları tespit etmek amacıyla, RTÜK'ün resmî internet sayfasından da yararlanılmıştır.

\section{Radyo ve Televizyon Yayınlarının Denetiminin Teorik Çerçevesi}

Günümüzün demokratik toplumlarında ifade özgürlüğü, en temel hak ve özgürlüklerin başında gelmektedir. Liberal yaklaşımın etkisiyle 18. yüzyılın son çeyreğinde Avrupa ve ABD'de hukukî bakımdan güvence altına alınmaya başlanan ifade özgürlüğünün sınırsız olup olmadığı ya da sınırlarının ne olması gerektiği hususu, tüm dünyada halen tartışılmakta ve farklı yaklaşımlar tarafından ele alınmaktadır.

Cohen'e göre (2000: 1-2), liberal demokratik prensiplerin işlediği yerlerde de ifade özgürlüğü bakımından birtakım sorunlar yaşanabilir. Her yeni olgu gibi, demokrasiler de antidemokratik ve liberal olmayan uygulamalarla mücadele etme konusunda deneyimsizdir. Esas odaklanılması gereken, özgürlük ve hoşgörü arasındaki sınırlardır. 
Her ne kadar liberaller, demokrasinin sınırları hakkında konuşmaktan pek hoşlanmasalar da sonuç odaklı birçok liberal düşünür, özgürlük, hoşgörü (Alf Ross, Alexander Meiklejohn, Franklin Haiman, Frederick Schauer, Lee Bollinger), haklar (Hugo Black, Aryeh Neier), eşitlik (Ronald Dworkin), hakikât (John Stuart Mill) ve adalet (John Rawls) gibi genel prensipler üzerinde dururlar. Amaç, özgürlük ve hoşgörünün geliştirilmesidir. Böylece, hükümetlerin yetkilerini kötüye kullanmalarının engellenmesi, farklı görüşlerin temsil edilmesinin sağlanması, çeşitliliğe ve çoğulculuğa saygı duyan ve demokrasiyi destekleyen bir sistemin var olması sağlanacaktır. Bu durumu iki yönlü bir prensiple açıklamak mümkündür. Bunlardan ilki; başkalarına zarar vermemek, ikincisi ise; diğer insanlara saygıyı teşvik etmektir.

İfade özgürlüğünün kötüye kullanılmaması hususunun, 1956 yılında basılan 'Basının Dört Teorisi' (Four Theory of the Press) adlı eserde üzerinde durulan 'Toplumsal Sorumluluk Teorisi' ile açıklandığını görmek mümkündür. Teoriye göre; hükümetler ifade özgürlüğünü yalnızca tanımamalı, ilerlemesini de teşvik etmelidir. Ancak, hükümetler gerektiğinde vatandaşlarının özgürlügünü korumak için bazı sınırlamalarda bulunabilir. Lakin bu sınırlamalar aşırıya kaçmamalıdır. Zira, özgürlüğü teşvik edebilen herhangi bir kurum, aynı zamanda onu yok etme yeteneğine de sahiptir. Oysa ifade özgürlüğü, liberalizmin temel yapı taşlarından biridir ve özellikle korunmalıdır (Siebert vd., 1984: 95).

Özgürlük ilkesi, sorumluluk ilkesine önderlik eder (Rawls, 2020: 271). Dolayısıyla, her ne kadar özgürlükçü bir perspektiften de bakılsa, özellikle kitle iletişim araçlarını, bu araçların ellerinde bulunan gücün kötüye kullanılmaması için makul sınırlar içinde denetlemek önem arz etmektedir. Bu durum, özgür ancak sorumlu bir basın-yayın anlayışının temelini oluşturmaktadır.

Şüphesiz, yayın organlarını ve özellikle de kamu yayın kuruluşlarını denetlemenin, 'kamu yararı'ndan öte gerekçeleri de mevcuttur. Burada, ekonomik, siyasal ve toplumsal süreçler devreye girmektedir. TRT'nin denetiminin niteliğini anlamak için, özellikle Avrupa'da İkinci Dünya Savaşı sonrasında yapılanan 'kamu hizmeti yayıncılı̆̆ı' modeline bakmak gerekmektedir. Çaplı'ya göre (2001: 33), bu dönemde, özellikle mevcut radyo dalgalarının sınırlı olması nedeniyle, yayıncılığın ancak devlet teklinde yürütülebileceği anlayışı ve siyasal iktidarların elektronik kitle iletişim araçlarından yararlanma konusundaki hırsları, kamu hizmeti yayıncılığı modelinin ortaya çıkmasını sağlamış ve bu sistem 1980'li yıllara kadar devam etmiştir.

İkinci Dünya Savaşı'ndan sonra radyo ve televizyon yayıncılığının devlet tekeli biçiminde yürütülmesinin tek nedeni, yukarıda bahsedilen hususlar değildir. Bu dönemde, Batı Avrupa'da halk, bilgi edinme ve haber alma ihtiyacını, savaştan kalma bir alışkanlıkla önemli ölçüde radyodan karşılıyordu. Ayrıca, devletin yayıncılık alanında başlıca girişimci olmas1, o dönem için garipsenecek bir durum değildi. Zira savaştan kaynaklanan krizlerin bir an önce atlatılabilmesi için Keynesçi ekonomi politikalar benimseniyor, devletin ekonomik ve toplumsal yaşama müdahalesi çözüm olarak görülüyordu. Demir yolları, silah, havacılık, bankacılık, elektrik, maden vb. birçok üretim ve hizmet alanında devlet faaliyet göstermekteydi. Böyle bir ortamda, televizyon yayınlarının devlet eliyle başlaması 
da gayet doğaldı (Akkor Gül, 2013: 23-24). Her ne kadar Avrupa ile Türkiye, benzer tarihsel süreçleri yaşamasalar da, özellikle Avrupa'da İkinci Dünya Savaşı sonrasında şekillenen kamu hizmeti yayıncılığının birtakım ilke ve özelliklerini 1964 yılında yayın hayatına başlayan TRT üzerinde de görmek mümkündür.

1960'lı yıllarda Türkiye'nin en temel sorununun 'kalkınma' olduğu tespit edilmiş, ulusal kalkınma ve demokratikleşme konusunda kitle iletişim araçlarına önemli roller atfeden modernleşme teorilerinin de etkisiyle, TRT'ye kalkınmanın sağlanması konusundaki tüm hususlar görev olarak verilmiştir (Kaya, 2009: 240). Bu bakımdan, özellikle 1960'lı yıllarda yapılan radyo yayınlarında 'eğlence' içerikleri artmakla birlikte, genel olarak geniş kitlelerin bilinçlenmesi yönünde yayınlara başvurulmuştur (Kocabaşoğlu, 2010: 486). Tüm bu hususlar, TRT'deki yayın denetiminin niteliğini etkilemiş ve hatta belirleyicisi olmuştur. Özellikle, yukarıda bir 'ideal' olarak sunulan ve ifade özgürlüğünün yalnızca 'kamu yararı' gerekçesi ile sınırlandırılması gerektiğini öngören yaklaşımların yerine -üstelik kitle iletişim araçlarının 'sınırlı' etkilerinin kabul görmeye başladığı bir dönemde- radyo ve televizyona toplumu bilinçlendirmenin, dönüştürmenin ve yönlendirmenin yegâne araçları gözüyle bakılmış ve sonraki başlıkta etraflıca ele alındığg üzere en başından günümüzde kadar geçen süreçte oldukça sıkı bir denetim yapısı kurulmuştur.

Bu noktada, TRT üzerinde nasıl bir denetim sağlanabileceği sorusu da önem arz etmektedir. Zira kitle iletişim araçlarını denetlemenin birçok yöntemi mevcuttur. Bunlar temelde; özdenetim, hukukî denetim ve izleyici denetimi olmak üzere üçe ayrılmaktadır. İzleyici denetimi, tüm kitle iletişim araçları üzerindeki en etkin denetim türü olarak kabul edilebilir. Ancak, finansmanları sadece reklamlar üzerinden sağlanmayan ve bütçelerinin büyük kısmı ruhsat ücretleri ve hükümet fonlarından oluşan kamu yayın kuruluşları, bu durumun istisnasını teşkil etmektedir. Yine benzer biçimde, 'kendi kendini denetleme' anlamına gelen ve saygın bir yayıncılık kültürüne hizmet edebilecek olan özdenetim uygulamaları da, özellikle hükümetler tarafından yeterli bulunmamaları nedeniyle kamu yayın kuruluşları bakımından tercih edilmemektedir. Dolayısıyla hukukî denetim, en başından itibaren Avrupa'da ve Türkiye'de yöneticiler tarafından kamu yayın kuruluşları için tercih edilen bir yöntem olmuştur.

\section{Tarihsel Süreç İçerisinde TRT Yayınlarının Denetimi}

Çalışmanın bu bölümünde TRT yayınlarının denetimi; TRT tekeli dönemi ve özel yayıncılığın başladığı dönem olmak üzere iki alt başlıkta ele alınmıştır.

\section{Tekel Döneminde TRT Yayınların Denetimi}

Türkiye'de, ilk radyo yayınının başladığı 1927 yılından 1964'e kadar geçen dönemde -ilk on yıl hariç- siyasî iktidar elinde ve tekelinde, bağıml1, 'hükümet sistemi'nin uygulandığı bir radyo yayıncılığ1 mevcuttur. 1961 Anayasası ilkelerinden esinlenerek hazırlanan 359 sayılı Türkiye Radyo-Televizyon Kurumu Kanunu(R.G. Tarih: 02.01.1964 / Sayı: 11596) ile söz konusu hükümet sistemi terk edilmiş, bunun yerine 'millî radyo sistemi’ benimsenmiştir (Gölcüklü, 1970: 214-215). Hem 1961 Anayasası'nda (m.121/1), 
hem de 359 sayılı Kanun'da (m.1/1) TRT'nin özerkliği açıkça kabul edilmiştir. Cankaya (1997: 24), özerkliği, Kurum'un program yapımında, yönetiminde ve ekonomik alanda siyasal iktidarlara bağlı olmaması olarak tarif etmektedir.

TRT'de 1966 yılında, Merkez Program Dairesi Başkanlığı bünyesinde denetim başlatılmıştır (Cankaya, 2003: 73). Bu dönemde, TRT yayınlarını düzenleyen birtakım ilke ve esaslar mevcuttur. Kurumun en yüksek yönetim ve denetim organı olan Yönetim Kurulu ve bu Kurul'un icra organı olan Genel Müdür, sahip oldukları hiyerarşik yetki sonucu yayınlanan programların denetçisi konumundadır. Söz konusu makamlar, kendiliğinden veya Danışma Kurulları aracılığı ile yayınları sansürden geçirmek, yayın yasağ1 koymak ve bir yayını durdurmak gibi yetkilere sahiptir (Gölcüklü, 1970: 235). Burada bahsedilen denetimi; 'ilk denetim' ve 'müdürlük denetimi'nden oluşan iki aşamalı bir hiyerarşik denetim olarak tanımlamak mümkündür. İlk aşamada, radyo ve televizyon müdürlüklerince hazırlanan program metni, bant ve filmler, müdürlüğün kendi içinde denetlenmektedir. Bu bakımlardan denetlenen program, ikinci aşama olan Denetim Müdürlüğ̈̈'ne gelmektedir. Her bir program, bu basamakta da ilk basamakta denetlenen açılardan denetlenmektedir. Eğer, bir program 'tekrar denetimi gerekir' kararıla geri çevrilirse, programcı tarafından yeniden düzenlenecek ve ilk denetimden başlamak üzere ayn1 yolları izleyecektir (Vural, 1994: 156-157).

Kamu kuruluşunun kendi kendini denetlemesine 'iç denetim' denilmektedir. İç denetimin en belirgin örneği ise; 'hiyerarşik denetim'dir (Gözübüyük, 2008: 365). Yukarıda da bahsedildiği üzere, TRT'nin ilk yıllarında başlayan denetim, bu tür denetimin belirgin bir örneğini teşkil etmektedir. Burada, bir idarî denetim türü olan 'hiyerarşik denetimi' açıklamak yerinde olacaktır. Gözler ve Kaplan'a göre (2011: 58, 60) hiyerarşi; idare içindeki görevliler arasındaki astlık-üstlük durumunu ifade eder. İl özel idaresi, belediye, köy gibi yer yönünden yerinden yönetim kuruluşlarının ve TRT, üniversite ve kamu iktisadi teşebbüsleri (KİT) gibi hizmet yönünden yerinden yönetim kuruluşlarının her birinde hiyerarşi ilişkisi mevcuttur. Bu bakımdan, üst, astın işlemlerini hem yerindelik, hem de hukukilik bakımından denetleyebilir. Denetim sonucunda astın işlemleri ilga edilebilir, geri alınabilir veya düzeltilebilir. Coşkun (2018: 129) 'üst'ün ast üzerindeki denetimi için, kanunî bir dayanağa gerek olmadığını, zira 'üst'ün astlarını denetleme görevinin, yönetme görevi içinde bulunduğunu belirtmektedir.

Denetimin niteliği bakımından, ‘ön denetim' anlamına gelen 'sansür' uygulaması mevcuttur. Bu arada, 1968 yılında TRT'de 'deneme yayını' niteliğinde televizyon yayınlarının başladığını da belirtmekte yarar bulunmaktadır. Böylece, yayın denetimi, radyo ile sınırlı olmaktan çıkmış ve televizyonu da kapsar hale gelmiştir.

1971 askerî müdahalesinden sonra, Anayasa'da birçok değişikliğe gidilmiş ve TRT'de bu değişikliklerden etkilenmiştir. 1488 sayılı Kanun (R.G. Tarih: 22.09.1971 / Sayı: 13964) ile Anayasa'nın 121. maddesinden TRT'nin özerkliği ifadesi çıkarılmış, yayıncılığın devlet tekelinde olacağı belirtilmiş ve yayınların tarafsızlık esasına göre yapılacağı hususu hükme bağlanmıştır. Ayrıca, 359 sayılı Kanun'da 1568 sayılı Kanun (R.G. Tarih: 08.03.1972 / Sayı: 14122) ile yapılan değişiklikle birlikte yayın esasları daha katı ve yoruma açık hale getirilmiştir (bkz Cankaya, 2000 ve 2003). Özerkliğin 
kaldırılmasının, hiyerarşik denetimi hükümet müdahalelerine çok daha açık hale getirdiğini söylemek yanlış olmayacaktır.

1980 askerî darbesinin ardından çıkarılan 1982 Anayasası da 1971 yılındaki bakış açısını devam ettirmiştir. Böylece, radyo ve televizyon kurmak ve işletmek devlet tekeli ile sınırlandırılmış, TRT'nin özerkliğinden bahsedilmemiş ve yayınların tarafsız olacağına vurgu yapılmıştır (m.133). Askerî müdahalelerin, bir kamu yayın kurumu olan TRT'nin niteliğini olumuz yönde etkilediğini görmek mümkündür.

Yeni Anayasa'nın ardından 359 sayılı Kanun ilga edilerek, yerine 2954 sayılı Türkiye Radyo ve Televizyon Kanunu (R.G. Tarih: 14.11.1983 / Sayı: 18221) çıkarılmıştır. İçel ve Ünver'e göre (2018: 401), bu Kanun'un önceki Kanun'dan en önemli fark1; TRT Kurumu Kanunu olmayıp Radyo Televizyon Kanunu niteliği taşımasıdır.

2954 sayılı Kanun ile mevcut olan ikili hiyerarşik denetime bir yenisi daha eklenmiştir. Kanun'a göre, TRT' de yayınlanacak programların son denetimi Genel Müdür adına ve Genel Müdür'e doğrudan bağlı 'Yayın Denetleme Kurulu Başkanlığg' tarafindan yapılacaktır (m.31/1). Söz konusu denetim, canlı yayın haricindeki programların ön denetimi yani sansür şeklinde gerçekleşecektir. Böylece uygun görülmeyen programların yayınına izin verilmeyecektir. Bu denetimi de hiyerarşik denetimin üçüncü bir ayağı olarak değerlendirmek mümkündür. Ayrıca, yeni düzenlemeyle birlikte, Türk Silahlı Kuvvetleri (TSK) ile ilgili yayınlar hakkında Genelkurmay Başkanlığı'nın olumlu görüşünün alınması hükme bağlanmıştır (m.31/2). Bu düzenleme, o dönemde Genelkurmay'ın güçlü etkisini göstermesi bakımından önem arz etmektedir.

Yeni Kanun'da göze çarpan en önemli husus; Radyo ve Televizyon Yüksek Kurulu (RTYK) adlı bir yapıya yer verilmesidir. RTYK'nın temel görevi; yurt içine yapılacak radyo ve televizyon yayınları için millî siyasete uygun ilkeleri tespit etmek ve Kurum'un, Kanun'un beşinci maddesinde belirtilen 13 yayın esasına uyup uymadığının denetim ve gözetimini yapmak olarak tanımlanmıştır (m.6/1). Çaplı'ya göre (2008: 11), bu dönemde halen TRT tekeli devam ettiği için RTYK, 'TRT Yüksek Kurumu' olarak nitelendirilmekteydi.

RTYK, “Cumhurbaşkanı tarafindan doğrudan atanacak üç üye, Bakanlar Kurulu tarafindan birisibasınmensubu olmaküzere eğitim veiktisatalanlarında veya hizmetlerinde temayüz etmiş kişiler arasından atanacak üç üye, Milli Güvenlik Kurulu'nca (MGK) seçilecek ve Bakanlar Kurulu tarafindan atanacak bir üye, Yükseköğretim Kurulunca (YÖK) elektronik ve hukuk bilimleri alanlarında temayüz etmiş kişiler arasından gösterilecek dört aday içinden Cumhurbaşkanı'nca seçilecek iki üye ve Atatürk Kültür, Dil ve Tarih Yüksek Kurumu Yönetim Kurulunca kültür ve sanat dallarında temayüz etmiş kişiler arasından gösterilecek altı aday içinden Cumhurbaşkanınca seçilecek üç üye” olmak üzere 12 üyeden oluşmaktadır (m.6/2). RTYK'nın yapısına bakıldığında, 12 üyenin tamamının hükümet tarafından seçildiğini görmek mümkündür.

RTYK'nın en temel görevi; radyo ve televizyon yayınlarının üç aylık yayınlarından gerekli görülenlerinin Kanun'a uygunluğunu yayın sonrasında denetlemek ve sonuçlarını Cumhurbaşkanı'na, Başbakan'a, Millî Güvenlik Kurulu Genel Sekreterliği'ne ve TRT'ye göndermektir (m.7/1-b). Bu düzenlemeyi, askerî darbe ortamının güvenliğini önceleyen 
politikalarının bir sonucu görmek mümkündür. RTYK'nın ayrıca, yayın esaslarına aykırı yapılan yayınlar hakkında idarî ve kanunî işlem yapılması amacıyla ilgili mercilere duyuruda bulunmak (m.7/1-c) ve TRT Yönetim Kurulu için on iki, Genel Müdürü için ise üç aday tespit ederek Bakanlar Kurulu'na sunmak (m.7/1-d) gibi iki önemli yetkisi bulunmaktadir.

RTYK denetimi ile TRT yayınları üzerinde üç ayaklı olarak gerçekleşen hiyerarşik denetimin yanına yeni bir tür denetimin eklendiği görülmektedir. Mevcut durum, RTYK ile kurulan idarî denetim olarak nitelendirilebilir. Ancak, bu denetim türünü, hiyerarşik denetimden farklı olarak 'dış denetim' olarak adlandırmak yerinde olacaktır. Akıncı' dan (1999: 81) yararlanarak, dış denetimi, bir kamu kuruluşunun eylem ve işlemlerinin başka bir kamu kuruluşu tarafından denetlenmesi olarak tanımlamak mümkündür.

Özerk olarak yapılandırılmayan bir yapı olan RTYK'nın, hiyerarşik denetimde olduğu gibi yayınlara 'ön müdahale'de bulunma ya da bir programı yayından kaldırma gibi somut yaptırımlarının bulunmaması da dikkat çekicidir. Tekinalp’e göre (2003: 114), RTYK'nın yaptırım yetkilerinin çok kısıtlı oluşu, yayıncılık üzerinde etkin bir denetim kurmasını engellemiştir.

2954 sayılı Kanunun getirdiği düzenlemeye bakıldığında iki türlü bir yayın denetim sistemi görülmektedir. Bu aşamalardan ilkini; kurum içi ön denetim şeklinde gerçekleşen hiyerarşik denetim, diğerini ise; RTYK'nın dış denetimi oluşturmaktadır. Her iki denetim türü de, idarî denetimin bir parçasıdır. RTYK denetimini, daha ziyade kurum denetimine ek olarak getirilen bir 'hükümet' denetimi olarak değerlendirmek yerinde olacaktır. Bu dönemde, Kurum'un özerkliği bulunmadığından, hiyerarşik denetim de hükümet yönlendirmelerine fazlaca açıktır. Farklı bir ifadeyle belirtmek gerekirse, 1980'li yıllarda Türkiye'de başlayan liberalleşme politikalarının aksine, bu dönemde TRT yayınlarının denetlenmesinde bir sıkılaşmaya gidildiği görülmektedir. Bu durumun gerçekleşmesinde, 1980 askerî darbesinin yarattığı otoriter ortamın da etkisi bulunmaktadır. Ayrıca, bahsedilmesi gereken diğer bir sorun da; yayınları denetleyen dört farklı mercii olması dolayısıyla (üç ayaklı kurum içi hiyerarşik denetim ve RTYK denetimi), bu merciler arasında bakış açısı farkı olabileceği ve bu durumun yayın denetimini belli bir standarttan uzaklaştırabileceği hususlarıdır. Zira Cankaya'nın da belirttiği üzere (1997: 65), 2954 sayılı Kanun'un 5. maddesinde öngörülen 'yayın esasları' muğlak niteliktedir. Örneğin, bu esaslarda geçen 'değer yargıları', 'umutsuzluk ve çaresizlik telkin edici', 'moral bozucu', 'genel ahlâk', 'millî gelenek ve göreneklerimiz' gibi kavramlar, denetçilerin ve yöneticilerin farklı yorumlar yapmasına neden olmuştur.

2954 sayılı Kanun ile içerik ve denetimin ayrıntıları, denetim ve reklam konularına ilişkin yönetmeliklere, yıllık genel yayın planlarına ve özel yayın esasları TRT'nin RTYK'nın tavsiyelerini alarak çıkaracağı düzenlemelere bırakılmıştır (Kejanlığlu, 2004: 238). Süreç, genel hatlarıyla özel yayıncılık alanında hukukî düzenlemeler yapılıncaya kadar bu şekilde sürmüştür. 


\section{Özel Yayıncıllk Döneminde TRT Yayınlarının Denetimi}

Türkiye'de özel yayınc1lk, 7 Mayıs 1990 tarihinde Liechtenstein'dan yayın yapmaya başlayan Star-1 ile başlamıştır (Coşkun, 2018: 104). Bir anlamda, TRT tekelinin kırılması anlamına gelen bu durum, daha önce bahsedilen Anayasa'nın 133. maddesine aykırı bir şekilde gerçekleşmiştir. Avrupa'nın bazı ülkelerinde de benzer şekilde gelişen bu 'de facto' özelleşme sürecine dönemin hükümeti tarafindan göz yumulmuş ve gayri hukukî düzen 1993 yılına kadar sürmüştür. Anayasa'nın 133. maddesinde 3913 sayılı Kanun (R.G. Tarih: 10.07.1993 / Sayı: 21633) ile yapılan değişiklikle birlikte "radyo ve televizyon istasyonları kurmak ve işletmek kanunla düzenlenecek şartlar çerçevesinde serbest" hale getirilmiştir.

Daha sonra yapılan değişikliği düzenlemek amacıyla 20 Nisan 1994 tarihinde 3984 sayılı Radyo ve Televizyonların Kuruluş ve Yayınları Hakkında Kanun (R.G. Sayı: 21911) yürürlüğe girmiştir. İlgili Kanunun 5. maddesi kapsamında, özerk ve tarafsız bir kamu tüzel kişiliği niteliğinde RTÜK oluşturulmuş ve söz konusu Kanun'u uygulamaya yetkili kılınmıştır. Kurulan yeni düzende RTÜK; hem TRT, hem de özel yayın kuruluşlarının yayın faaliyetlerini düzenleme, denetleme ve yaptırım uygulama yetkisine sahip olmuştur.

3984 sayılı Kanun'un TRT bakımından getirdiği ilk değişiklik, RTYK'nın görevinin sona ermesi ve TRT Yönetim Kurulu ile Genel Müdürü için aday belirleme yetkisinin RTÜK'e devredilmesidir (m.36). Ayrıca TRT, Kanun'da belirtilen yayın ilke ve esaslarına uymakla yükümlü kılınmıştır (m.35). Bir anlamda, TRT üzerinde RTYK ile kurulan dış denetim sistemi, RTÜK ile devam ettirilmiştir. Ayrıca, TRT içerisindeki hiyerarşik denetim de devam etmektedir.

Yapısal bakımından incelendiğinde, RTYK'nın ilga edilmesiyle, TRT üzerindeki denetimin niteliğinin değiştiği görülmektedir. Zira RTÜK, doğrudan hükümetlere bağl1 bir yapı olmayıp 'bağımsız idarî otorite' (independent regulatory agency) adı verilen farklı bir denetim mercidir. Bu bakımdan, öncelikle bağımsız idarî otorite kavramını tanımlamak yerinde olacaktır. Bu türden kurumlar, siyasî organlardan bağımsız, temel hak ve özgürlüklerle ekonomik etkinliklerin duyarlı olduğu konularda, araştırma, önerme, düzenleme, denetim ve gözetim yapan kuruluşlardır (Giritli, vd.; 2006: 194). Bağımsız idarî otoriteler, özerk ve bağımsız yapıda olup hiyerarşik ve vesayet denetimi dışındadırlar.

Teknolojik gelişmelere açık olmaları, toplumsal yaşamda özel bir öneme sahip olmaları, ayrıca temel hak ve özgürlüklerle doğrudan ilgileri nedeniyle 'duyarlı sektörler' olarak kabul edilen; iletişim, medya, ekonomik rekabet, enerji, telekomünikasyon, bankacılık vb. gibi alanların, hem politikacıların hem de ilgili sektörlerde faaliyet gösteren aktörlerin etkisinden arındırılmaları ihtiyacı ve amacı, bağımsız idarî otoritelerin doğmasının en önemli nedeni olmuştur. Bu kurumları, diğer kurumlardan ayıran en önemli özellik; üyelerinin görev süresi dolmadan görevden alınamamalarıdır (Ulusoy, 2003: 5, 17). Ayrıca, bu kurumların bağımsızlığından anlaşılması gereken, personelinin her türlü siyasî baskı ve telkinden uzak olmasıdır (Odyakmaz vd., 2011: 512). Özerklik ise; bir hizmetin görülmesindeki kamu yararını hem siyasî iktidar, hem de özel çıkarlar ve bunların ekonomik gücü karşısında koruyan bir araçtır (Akıncı, 1999: 109). Farklı 
bir ifadeyle belirtmek gerekirse bağımsız idarî otoriteler; 1980'li yıllardan itibaren tüm dünyada benimsenen liberalleşme politikalarının etkisiyle, devletlerin piyasa alanından çekilmeye başlaması sürecinde, devlete ve sektöre eşit mesafede duracağı varsayılan bir 'hakem' arayışı sonucunda ortaya çıkmıştır.

RTÜK, gerek Anayasa'nın 133. maddesi, gerekse 3984 sayılı Kanun'a göre, yukarıda sayılan özelliklere sahip bir bağımsız idarî otorite olarak düzenlenmiştir. O dönemde böyle bir yapıya ihtiyaç duyulmasının temel nedeni; yayıncılık alanında özel şirketlerin faaliyet göstermeye başlaması ve devletin bu hassas alanı doğrudan kendine bağlı bir yapı aracılığı ile denetlemeyi tercih etmesidir. Ancak belirtmek gerekir ki; 3984 sayılı Kanun, yaklaşık dört yıl süren 'kuralsız' yayıncılık döneminin kusurlarını ortadan kaldırmak amacıyla RTÜK'e olağanüstü yetkiler vermiştir. Devlet ile sektör arasında hakem olması beklenen bir bağımsız idarî otoritenin özellikle katı yaptırım yetkileri ve sert uygulamaları, sonraki yıllarda Türkiye'nin Avrupa Birliği adaylık sürecinde de eleştiriler almasına yol açmıştır. Bu dönemde, RTÜK'ün TRT ile ilişkileri de sorunlu bir biçimde başlamıştır. Dönemin RTÜK Başkanlarından Sedat Nuri Kayış’a göre (2006: 19), bu düzenlemeden sonra TRT, RTÜK ile her zaman iyi geçinmek zorunda olan bir konumda olmuş ve bu tablo, bazı RTÜK üyelerinin TRT yöneticilerini işe alımlar konusunda istismar etmeleri sonucunu doğurmuştur.

RTÜK ile başlayan yeni denetim sisteminin TRT üzerindeki en problemli tarafı ise; yaptırımların niteliği konusunda olmuştur. 3984 sayılı Kanun'da, özel yayın kuruluşları için önce 'uyarı' yaptırımı ve ihlâlin tekrarı halinde ise bir yıla kadar geçici 'yayın durdurma' yaptırımı öngörülmüş iken (m.33), TRT için 'uyarı' yaptırımından sonra ihlâlin tekrar etmesi durumunda Genel Müdür'ün ve Yönetim Kurulu'nun görevlerinin düşeceği hükme bağlanmıştır (m.35). Dolayısıyla özel yayıncılar ile TRT'ye farklı yaptırımların öngörülmüş olması, hukuktaki eşitlik ilkesine aykırılık teşkil etmektedir.

3984 sayılı Kanun'un TRT üzerindeki ağır yaptırımı, RTÜK göreve başladıktan kısa bir süre sonra gerçekleşmiştir. 21 Temmuz 1994 tarih ve 127 sayılı RTÜK kararı ile "demokratik gruplar ve siyasî partiler arasında firsat eşitliğinin sağlanması" yayın ilkesinin ihlâli gerekçesiyle TRT Kurumu uyarılmış, aynı ilkenin 30 Ekim 1995 tarihinde yeniden ihlâli nedeniyle, TRT Genel Müdürü Tayfun Akgüner ve Yönetim Kurulu'nun düşürülmesine Üst Kurul tarafından karar verilmiştir. TRT tarihinde ilk kez gerçekleşen bu olay üzerine Tayfun Akgüner, Ankara 2. İdare Mahkemesi'nde göreve iadesine ilişkin dava açmış ve dava, 13 Şubat 1996 tarihinde Akgüner lehine sonuçlanmıştır. Ancak davanın peşini bırakmayan RTÜK, bir üst mahkeme olan Danıştay’a itiraz etmiş, Danıştay RTÜK'ü haklı bulmuş ve Akgüner, 9 Eylül 1996 tarihinde görevden ayrılmak durumunda kalmıştır (Serim, 2007: 173-174). Sonuç olarak, TRT gibi önemli bir kurumda bir yıla yakın süren bir yönetim krizi yaşanmıştır.

1994 yılından itibaren TRT üzerinde geçerli olan denetim sistemi, 1983-1994 arası dönem ile farklılık arz etmektedir. Bu durumun en önemli nedeni; RTYK'nın özerk olmayan ve doğrudan hükümetlere bağlı bir yapı arz etmesi, RTÜK'ün ise özerk ve 
bağımsız bir kurum olmasından kaynaklanmaktadır. Ayrıca RTYK' nın yaptırım gücü zayıf iken RTÜK, ciddi yaptırımlarla donatılmıştır. Ancak uygulamaya bakıldığında, özerk bir kuruluşun TRT üzerinde daha şeffaf bir denetim uygulayabileceği varsayılırken, TRT bakımından RTYK döneminde yaşanmayan sorunların RTÜK döneminde yaşandığını görmek mümkündür.

1994-2002 yılları arasındaki dönemde TRT üzerindeki yayın denetiminin yapısı; kurum içi hiyerarşik denetim ve bir bağımsız idarî otorite olan RTÜK'ün dış denetimi olmak üzere iki aşamadan oluşmaktadır. Hiyerarşik denetimde uygulanan ön denetim yerine, RTÜK denetimi yayından sonra gerçekleşmektedir. Farklı bir ifadeyle belirtmek gerekirse, RTÜK tarafından denetlenen TRT yayınlarının birçoğu, halihazırda zaten TRT'de kurum içi denetimden geçen yayınlardan oluşmaktadır. Bir yayını birbirinden farklı kurumların denetlemesi, denetimi fazlaca 'sıkı' hale getirmektedir'. Ayrıca, her iki kurumun programlardan beklentisinin, kamu yararı anlayışının, yayın ilkelerinin ve bu yayın ilkelerini uygulama ve yorumlama biçimlerinin birbirinden farklı olabileceği düşünüldüğünde, iki kurumun uygulamaları arasında farklılık olması kaçınılmazdır. Örneğin, TRT denetçileri tarafından uygun bulunan bir programın, RTÜK için sakınca arz edebilmesi gayet mümkündür. Bu konudaki çözüm önerilerine, çalışmanın son kısmında etraflıca değinilmiştir.

RTÜK'ün TRT üzerindeki yaklaşık sekiz yıl süren denetimi, 3984 sayılı Kanun'da birçok değişiklik öngören 4756 sayılı Kanun'un (R.G. Tarih: 21.05.2002 / Sayı: 24761) yürürlüğe girmesiyle son bulmuştur. Kanun'un yaptırımları düzenleyen 33. maddesinde yapılan değişiklikle, yaptırımların 'özel' radyo ve televizyon kuruluşlarına uygulanacağı belirtilmiş ve TRT, RTÜK denetiminin kapsamından çıkarılmıştır.

Diğer yandan, 2005 y1lında Anayasa'nın 133. maddesinde değişikliğe gidilmiş ve TRT'nin özerkliği kabul edilmiştir. Bu doğrultuda, 2008 yılında 2954 sayılı Kanun'da yapılan değişiklik ile Kurum'un özerkliğinin Anayasa tarafından hükme bağlandığı ifade edilmiş (m.1) ve özerklik tanınmıştır. Ancak, söz konusu özerklik, uygulamada hiçbir zaman gerçekleşememiştir. Zira Kurum, mevzuat gereğince doğrudan hükümetlere bağl1 olarak yapılandırılmıştır.

\section{Günümüzde TRT Yayınlarının Denetimi}

Günümüzde TRT yayınları, belirli açılardan 6112 sayılı kanun kapsamında denetlenmektedir. Çalışmanın bu bölümünde, RTÜK kararları çerçevesinde TRT'nin ihlâlleri ile uygulanan yaptırımlar üzerinde durulmuştur.

\section{Sayılı Kanun Bakımından TRT Yayınlarının Denetimi}

6112 sayılı Radyo ve Televizyonların Kuruluş ve Yayın Hizmetleri Hakkında Kanun, 3 Mart 2011 tarihinde 3984 sayılı Kanun'u ilga ederek yürürlüğe girmiştir. Yeni Kanun, Avrupa Birliği’nde yayıncılık alanını düzenlemek amacıyla 2007 yılında

3 Coşkun (2018: 178) da sıkı ve sıklıkla yapılan radyo ve televizyon yayıncılığı denetiminin, bu alanda önemli yer tutan ifade ve yayın özgürlüğü ile program düzenleme serbestliğinin zedelenmesine, tam olarak kullanılamamasına ve hatta yok olmasına yol açabileceğini belirtmektedir. 
yürürlüğe giren Avrupa Birliği (AB) Görsel-İşitsel Medya Hizmetleri Yönergesi’ne (GİMHY) uygun olarak hazırlanmıştır. Farklı bir ifadeyle belirtmek gerekirse, yayıncılık alanında düzenlemeye gidilmesinin temel amacı; AB'ye uyum sağlanmasıdır.

GİMHY'de, söz konusu yönergenin kapsamının kamu hizmeti yayın kuruluşlarını da kapsadığı belirtilmiştir (m.21/2). 6112 sayılı Kanun da GİMHY ile uyumlu olarak yeniden TRT'yi denetim kapsamına almıştır. Buna göre TRT, yeni Kanun'un 8. maddesinde belirtilen yayın hizmeti ilkeleri ile yayın hizmetlerinde ticarî iletişimi düzenleyen hükümlerinden sorumlu tutulmuştur (m. 45/1). Ayrıca, Türkiye Radyo-Televizyon Kurumu Programlarının Denetimi Hakkında Yönetmelik'te (R.G. Tarih: 08.07.1999 / Sayı: 23749) 2014 yılında yürürlüğe giren değişiklikle (R.G. Tarih: 04.04.2014 / Sayı: 28962), programların denetiminde TRT'nin yayın esaslarının yanı sira 6112 sayılı Kanunun 8. maddesinde sayılan yayın hizmeti ilkeleri ile reklam yayınlarını düzenleyen kanun hükümlerinin de dikkate alınacağı hükme bağlanmıştır (m.5/1-a-b).

Denetimin yapısına bakıldığında yeni sistemle birlikte, TRT'ye yönelik uygulamalarda 2002 yılının öncesine dönüldüğü görülmektedir. Bu durumu; ikisi kurum içi hiyerarşik, birisi de dış denetim olmak üzere üçlü bir idarî denetim mekanizması olarak nitelendirmek mümkündür. Bakanlıklara Bağlı, İlgili, İlişskili Kurum ve Kuruluşlar ile Diğer Kurum ve Kuruluşların Teşkilatı Hakkında Cumhurbaşkanlığı Kararnamesi'ne ${ }^{4}$ göre (R.G. Tarih: 15.07.2018 / Sayı: 30479); TRT Kurumu'nun yayınlayacağı programların son denetimi, Genel Müdür adına yayın denetmenleri tarafından yapılmaktadır (m.545/1). Daha detaylı olarak düzenlenen TRT Kurumu Programlarının Denetimi Hakkında Yönetmeliğe göre ise; yayına verilecek her türlü programın ilk denetiminden program yapımcısı ve ilgili ünite yetkilisi sorumludur (m.12/4). Hiyerarşik denetimin diğer aşamasını ise; Yayın Denetleme ve Koordinasyon Kurulu Başkanlığ ${ }^{5}$ tarafından gerçekleştirilen denetim oluşturmaktadır (m.6). Yönetmeliğe göre, haberler ve spor yayınları denetimden muaf tutulmuştur (m.4/1-c). Ayrıca, canlı yayınlanan programlardan; programı hazırlayan, yöneten, sunan, yapımına ve yayınına izin veren ünite yetkilisi ile ilgili daire başkanı müteselsilen sorumludur (m.12/2). İdarî denetimin son halkasını ise, yukarıda da belirtilmiş olduğu üzere, bir dış denetim organı olan ve bağımsız idarî otorite niteliğinde bulunan RTÜK denetimi oluşturmaktadır.

Yeni sistemle birlikte, TRT üzerinde yeniden çok katmanlı ve katı bir denetim yapısı kurulduğu görülmektedir. Ancak asıl dikkati çeken husus; 6112 sayılı Kanun bakımından TRT için öngörülen yaptırımlardır. TRT Kurumu, yayınlarında Kanun'un 8. maddesi ile reklam yayınları ile ilgili ilke ve esaslara aykırı yayın yapması durumunda Üst Kurul tarafindan uyarılacak ve söz konusu karar ilgili Bakanlığa bildirilecektir (m.45/2). Oysa özel radyo ve televizyon kuruluşları için 6112 sayılı Kanun'un öngördüğü yaptırımlar farklıdır. Bu kuruluşlara, bir önceki ayın brüt iletişsim gelirlerinin yüzde biri ile beşi arasında para cezası, beş kereye kadar program durdurma, yayın durdurma ve lisans iptali gibi oldukça ağır yaptırımlar öngörülmüştür (m.32). 3984 sayılı Kanun'da özel yayıncılara

4 Türkiye'de 2018 yılından itibaren uygulanmaya başlanan Cumhurbaşkanlığı Hükümet Sistemi de TRT'nin yapısında birtakım değişiklikler meydana getirmiş ve TRT Cumhurbaşkanlığı'na bağlanmıştır.

55767 say1lı Kanun'un (R.G. Tarih: 26.06.2008 / Say1: 26918) 10. maddesiyle, 2954 say1l Kanun'un 31. maddesinde geçen 'Yayın Denetleme Kurulu Başkanlığı' ibaresi 'Yayın Denetleme ve Koordinasyon Kurulu Başkanlığı' şeklinde değiştirilmiştir. 
nazaran TRT için daha ağır yaptırımlar öngörülmüş iken, 6112 sayılı Kanun'da bu durum tam tersine dönmüştür. Her iki Kanun'un da ortak özelliği; yayıncılığın iki ayağını oluşturan kamu hizmeti yayıncıları ile özel yayıncılar arasında yaptırımlar bakımından dengeyi ve eşitliği sağlayamamış olmalarıdır.

\section{RTÜK Kararları Çerçevesinde TRT'nin İhlâlleri ve Uygulanan Yaptırımlar}

Çalışmanın bu kısmında, 6112 sayılı Kanun'un yürürlüğe girdiği tarih olan 3 Mart 2011 tarihinden günümüze kadar geçen sürede, TRT'nin 6112 sayılı Kanun'un 8. maddesi ile reklam ilke ve esaslarını düzenleyen maddelerini ihlâl ettiği gerekçesiyle Üst Kurul tarafından alınan yaptırım kararları incelenmiştir. Söz konusu ihlâller aşağıdaki tabloda listelenmiştir (rtuk.gov.tr, 17.08.2021).

Tablo 1: RTÜK Kararları Çerçevesinde TRT'nin İhlâlleri ve Uygulanan Yaptırımlar

\begin{tabular}{|c|c|c|c|c|}
\hline & $\begin{array}{l}\text { YAYINCI } \\
\text { KURULUŞ }\end{array}$ & $\begin{array}{l}\text { İHLAL } \\
\text { TARİHİ }\end{array}$ & $\begin{array}{c}\text { İHLAL EDİLEN İLKE VE } \\
\text { HÜKÜMLER }\end{array}$ & YAPTIRIM \\
\hline 1 & TRT MÜZİK & 29.06 .2013 & $\begin{array}{l}\text { Türkçe'ye uygunluk / argo } \\
\text { kullanım }(\mathrm{m} .8 / 1-\mathrm{m})\end{array}$ & Uyarı \\
\hline 2 & TRT HABER & 21.08 .2013 & İnsan onuruna aykırılık (m.8/1-ç) & Uyar1 \\
\hline 3 & TRT1 & 22.08 .2013 & İnsan onuruna aykırılık (m.8/1-ç) & Uyarı \\
\hline 4 & TRT1 & 05.04 .2015 & Şiddetin özendirilmesi (m.8/1-ş) & Uyar1 \\
\hline 5 & TRT HABER & 05.05 .2015 & $\begin{array}{c}\text { Yayınlarda hukukun üstünlüğ̈ü } \\
\text { ilkesi (m.8/1-c), İnsan onuruna } \\
\text { aykırılık (m.8/1-ç), tarafsızlık } \\
(\mathrm{m} .8 / 1-1)\end{array}$ & Uyar1 \\
\hline 6 & TRT1 & 27.07.2015 & $\begin{array}{c}\text { Yayınlarda çocukların ve gençlerin } \\
\text { korunmas } 1(\mathrm{~m} .8 / 2)\end{array}$ & Uyarı \\
\hline 7 & TRT1 & 25.09 .2015 & $\begin{array}{l}\text { Program tanitımında sponsor fir- } \\
\text { maya atıfta bulunma (m.12/1) }\end{array}$ & Uyar1 \\
\hline 8 & TRT HABER & 12.10 .2015 & $\begin{array}{l}\text { Kişi ya da kuruluşları küçük } \\
\text { düşürücü yayın (m.8/1-ç) }\end{array}$ & Uyar1 \\
\hline 9 & TRT1 & 14.10 .2015 & Ayrımcılık içeren yayın (m.8/1-e) & Uyar1 \\
\hline 10 & TRT HABER & 09.02 .2016 & $\begin{array}{c}\text { Siyasî partiler bakımından tarafsız } \\
\text { yayın }(\mathrm{m} .8 / 1-\mathrm{k})\end{array}$ & Uyarı \\
\hline 11 & TRT WORLD & 13.03.2016 & $\begin{array}{c}\text { Yayınlarda hukukun üstünlüğü } \\
\text { ilkesi (m.8/1-c) }\end{array}$ & Uyarı \\
\hline 12 & TRT BELGESEL & 27.03 .2016 & Şiddetin özendirilmesi (m.8/1-ş) & Uyarı \\
\hline 13 & TRT1 & 12.06 .2016 & Ayrımcılık içeren yayın (m.8/1-e) & Uyar1 \\
\hline 14 & TRT AVAZ & 15.06 .2016 & Ayrımcılık içeren yayın (m.8/1-e) & Uyar1 \\
\hline 15 & TRT1 & 18.09.2016 & $\begin{array}{c}\text { Türkçe'ye uygunluk / argo } \\
\text { kullanımı (m.8/1-m) }\end{array}$ & Uyarı \\
\hline 16 & TRT1 & 18.01.2018 & $\begin{array}{l}\text { Program tanıtım süresinin aşılması } \\
(\mathrm{m} .10 / 3)\end{array}$ & Uyar1 \\
\hline 17 & TRT BELGESEL & 04.03 .2018 & $\begin{array}{l}\text { Türkçe'ye uygunluk / argo } \\
\text { kullanımı (m.8/1-m) }\end{array}$ & Uyarı \\
\hline 18 & TRT DIYYANET & 22.06 .2018 & $\begin{array}{l}\text { Terörün amaçlarına hizmet edebi- } \\
\text { lecek türden yayınlar (m.8/1-t) }\end{array}$ & Uyarı \\
\hline 19 & TRT HABER & 05.11 .2020 & Tarafsızlık (m.8/1-1) & Uyar1 \\
\hline
\end{tabular}


Tablodan da anlaşılacağı gibi, yaklaşık sekiz yıllık süreçte Üst Kurul tarafından TRT'ye 19 farklı yaptırım uygulanmıştır. Dolayısıyla TRT'nin bu süreçte, 6112 sayılı Kanun' da öngörülen yayın hizmeti ilkelerini ve ticarî iletişimle ilgili öngörülen hükümleri 19 kez ihlâl ettiği sonucuna ulaşılmıştır. Ancak buradaki esas mesele, TRT’nin kaç ihlâl yaptı̆̆ 1 değil, önceki başlıkta da belirtildiği üzere TRT Kurumu'na, özel yayıncılardan daha hafif yaptırımlar uygulanmış olmasıdır. Örneğin, 6112 sayılı Kanun'un 8. maddesinin birinci fikrasının ' $s$ ' ve ' $t$ ' bentlerini ihlâl eden yayın kuruluşları için bir önceki ayın brüt iletişim gelirlerinin yüzde ikisi ile yüzde beşi arasında para cezası ve/ veya beş kereye kadar program durdurma yaptırımı öngörülmüş iken (m.32/1), bu ilkeleri 05.04.2015, 27.03.2016 ve 22.06.2018 tarihlerinde ihlâl eden TRT için yalnızca uyarı yaptırımı uygulanmıştır. Diğer 16 ihlâl için ise; özel yayın kuruluşları için bir önceki ayın brüt iletişim gelirlerinin yüzde biri ile yüzde üçü arasında para cezası öngörülmüş iken (m.32/2), TRT kurumu yalnızca uyarılmıştır.

İdarî yaptırımların kapsamı göz önünde bulundurulduğunda, çifte standarda sahip bir değerlendirme ortamının oluştuğunu belirten Coşkun (2018: 306-307), TRT Kurumunun uyarıya konu olacak ihlâli tekrarlaması durumunda nasıl bir yaptırımla karşı karşıya kalınacağının da kanun koyucu tarafından belirtilmediğine dikkat çekmektedir. Dolayısıyla, 6112 sayılı Kanun'un öngördüğü yaptırım sistemi, özel yayıncılar ile TRT bakımından belirgin bir eşitsizlik yaratmaktadır. Özellikle, görece çok izlenen bir ulusal yayın kuruluşunun, bir aylık brüt iletişim gelirlerinin yüzde birinin dahi oldukça önemli miktarlara tekabül ettiği düşünüldüğünde, aynı yayın hizmeti ilkesinin ihlâli nedeniyle özel yayın kuruluşu milyonlarca liralara varan idarî para cezasına maruz bırakılırken, TRT Kurumu ise yalnızca uyarılmaktadır.

Bu noktada mevcut sorunu çözmek için iki farklı yol önerilebilir. Bunlardan ilki; 3984 sayılı Kanun'da 2002 yılında yapılan değişiklik ile benzer olarak TRT Kurumu'nu RTÜK denetiminden çıkarmaktır. Zira TRT, önceki kısımlarda da belirtildiği üzere özel yayın kuruluşlarına nazaran oldukça katı bir kurum içi hiyerarşik yayın denetimine sahiptir. Dolayısıyla, TRT'nin RTÜK denetimi dışında bırakılması, bu kurumun 'denetimsiz' kalacağı anlamına gelmeyecektir. Ancak, 2954 sayılı Kanun'da ve ilgili TRT Yönetmeliklerinde öngörülen yayın ilke ve esasları ile 6112 sayılı Kanun'da ve RTÜK Yönetmeliklerinde öngörülen ilke ve esaslar arasında birtakım farklılıklar ve hatta çelişkiler olabileceği düşünüldüğünde, önerilen bu sistemde de özel yayıncılar ile TRT'nin denetimi bakımından niteliksel bazı farklar ve eşitsizlikler olabileceğini göz önünde bulundurmak gerekmektedir.

Diğer bir çözüm önerisi ise; mevut durumun devam etmesi ancak yaptırımların özel yayın kuruluşları ve TRT bakımından 'mümkün olabildiğince' eşit hale getirilmesidir. Bu bakımdan, TRT Kurumu'na 'uyarı' yaptırımının yanı sıra 6112 sayılı Kanun'daki yaptırımların ana unsurunu oluşturan 'idarî para cezası' ve 'program durdurma' yaptırımlarını uygulamak mümkündür. Özellikle, bir kamu kurumunun diğer bir kamu kurumuna 'para cezası' yaptırımı uygulaması, üzerinde tartışılabilecek bir husus olsa da, bu durumun dünyada ve Türkiye'de örnekleri mevcuttur.

Kamu yayın kuruluşlarına idarî para cezası uygulanması konusunda verilecek en önemli örnek; dünyada yayıncılık hukukunun en gelişmiş olduğu ülkelerden biri olan 
İngiltere'dir. Yayıncılık alanını düzenleyip denetlemekle görevli Ofcom (Office of Communications), bu alandaki mevzuatın kendisine verdiği yetkiye dayanarak köklü kamu yayın kuruluşu BBC'ye, ihlâlde bulunan programın tekrar yayınlanması, ihlâlle ilgili düzeltme yayınlanması ve para cezası gibi yaptırımlar uygulayabilmektedir (ofcom. org.uk, 03.04.2017). Benzer uygulamalara Türkiye'de de başvurulmaktadır. 6 Eylül 2009 tarihinde TRT2'de yayınlanan 'Aman Adanalı' adlı belgeselde sigaralı sahnelerin yer alması nedeniyle TRT’ye, RTÜK tarafından 4207 sayılı Türün Ürünlerinin Zararlarının Önlenmesi ve Kontrolü Hakkında Kanun'un (R.G. Tarih: 26.11.1996 / Say1: 22829), "televizyon programlarındaki içeriklerde tütün ürünlerinin kullanılamayacağl ve görüntülerine yer verilemeyeceği ” hükmü (m.3/6) gereğince elli bin lira idari para cezas1 uygulanmıştır (www.cumhuriyet.com.tr, 28.02.2010). Yine benzer biçimde Üst Kurul kararları incelendiğinde; 6 Ekim 2013 tarihindeki yayını nedeniyle TRT1'e, 4207 sayılı Kanun uyarınca para cezası uygulandığı görülmektedir.

Hukuk devleti, aynı zamanda benzer olaylara benzer işlemler yapılması kuralını ifade eder (Rawls, 2020: 266). Dolayısıyla da yukarıda belirtildiği üzere, TRT Kurumu için 6112 sayılı Kanun'da idarî para cezası ve program durdurma gibi yaptırımların öngörülmesi, özel yayıncılar ile TRT arasında hukukî bakımdan bir eşitlik sağlayacaktır. Ancak, TRT'nin bir kamu yayın kuruluşu olması ve bir önceki başlıkta ele alınan 15 Temmuz 2018 tarihli Resmî Gazete'de yayınlanan Cumhurbaşkanlığı Kararnamesi'ne göre; özellikle millî eğitim ve kültürün geliştirilmesine (m.534/1-d-3), devletin milli güvenlik siyasetinin, millî ve ekonomik menfaatlerinin korunmasına katkı sağlamak (m.534/1-d-4), yurt dışına yapılacak yayınlarda devletin her alanda tanıtılması (m.534/1-e-1) ve yurt dişında bulunan Türk vatandaşlarının Türkiye Cumhuriyeti ile ilişkilerinin sürdürülmesine yardımcı olmak (m.534/1-e-2) gibi kamusal birtakım görevleri bulunduğundan, 6112 sayılı Kanun'un 32. maddesinde öngörülen yaptırımlardan 'belirli bir süre için yayın durdurma' ve 'lisans iptali' gibi yaptırımlara maruz kalması mümkün değildir. Dolayısıyla, önerilen bu sistem de TRT ile özel yayıncıları 'mümkün olabildiğince' eşit hale getirecektir.

TRT Kurumu'nun dış idari denetleyici olan RTÜK tarafından, yukarıda önerilen şekilde denetimine devam edilmesi halinde, TRT bünyesinde gerçekleştirilen iki aşamalı hiyerarşik denetimin yumuşatılması yerinde olacaktır. Zira, daha önce de belirtildiği üzere, bir kurum üzerinde iki farklı denetleyici merci bulunması hem ifade özgürlüğü bakımından birtakım sorunlar yaratabilir, hem de bu mercilerin uygulamaları birbirleriyle çelişebilir. Bu durum, denetimde belirli bir standarttan uzaklaşılması anlamına gelmektedir. Önerilen husus; TRT'de kurum içi katı bir hukukî denetim sistemi yerine, yayıncılık bakımından modern etik ilkelerin kabul edilmesi ve bu ilkelere uyulup uyulmadığının editöryal denetiminin yapılmasıdır. Böylelikle, objektif bir RTÜK denetiminden önce, gönüllü bir özdenetim anlayışı öne çıkacaktır.

\section{Sonuç}

Bazı liberal düşünürlere göre ve Toplumsal Sorumluluk Teorisi'nin bir gereği olarak, kitle iletişim araçları makul sınırlar içerisinde denetlenmelidir. Denetimin temel amacı, bu araçların başkalarına zarar vermemesinin sağlanması ve ifade özgürlügüünün kişi ve kurumlar tarafından kötüye kullanılmasının engellenmesidir. Amaç; özgür ancak sorumlu bir yayıncılık ortamının sağlanmasıdır. 
1964 yılında kurulan TRT, eğlendirici içeriklerden ziyade toplumu bilinçlendiren, yönlendiren ve dönüştüren içeriklere ağırlık veren bir kamu yayın kuruluşu olmuştur. $\mathrm{Bu}$ durum, en başından beri TRT yayınları üzerindeki denetimin niteliğini etkilemiş, Kurum'un yüklendiği toplumsal misyon, yayınların daha sıkı denetlenmesine neden olmuştur.

Özerk bir kurum olarak yayın hayatına giren TRT'de, merkezî yayın denetimi 1966 yılında başlamıştır. 1971 askerî müdahalesinin bir sonucu olarak TRT'nin özerkliği kaldırılmıştır. Dolayısıyla, yayınların denetimi bu gelişme ile hükümet müdahalelerine daha açık hale gelmiştir. 359 sayılı Kanun'un öngördüğü iki aşamalı kurum içi hiyerarşik denetim, 1983 yılında 2954 sayılı Kanun yürürlüğe girene kadar sürmüştür. Yeni Kanun, Yayın Denetleme Kurulu Başkanlığı'nı getirerek kurum içi hiyerarşik denetim basamaklarına bir yenisini daha eklemiştir. Bu döneme kadar TRT üzerinde herhangi bir dış denetleyici bulunmamakla birlikte, 2954 sayılı Kanun TRT'nin çok katmanlı kurum içi hiyerarşik denetimine RTYK'nın dış idarî denetimi eklenmiştir. Yayınların, bu kadar fazla yapı tarafindan denetlenmesi, şüphesiz ifade özgürlüğü tarafından problemli bir durumdur. Ancak yapısal olarak bakıldığında, 2954 sayılı Kanun'la mevcut denetim daha sıkı hale gelse de özellikle RTYK'nın yaptırım yetkilerinin sınırlı olması dolayısıyla denetimin niteliğinde çok büyük bir fark yaşanmamıştır.

TRT yayınlarının denetimi bakımından asıl kırılma noktas1; özel yayıncıları düzenleyip denetlemek amacıyla RTÜK'ün kurulması ve 3984 sayılı Kanun'un özel yayıncılarla birlikte TRT'yi de RTÜK denetimi kapsamına almasıyla gerçekleşmiştir. Bağımsız bir idarî otorite olması dolayısıyla TRT üzerinde daha şeffafbir denetim sağlaması beklenen RTÜK, TRT yayınlarının denetimi bakımından daha önce karşılaşılmayan sorunlara yol açmıştır. Buradaki temel problem, TRT yayınlarının RTÜK tarafından denetlenmesi değil, 3984 sayılı Kanun'un özel yayıncılara nazaran TRT için çok ağır bir yaptırım öngörmüş olmasıdır. RTÜK'ün 1995 yılında TRT'ye yayın ilkesi ihlâli nedeniyle uyguladığı yaptırım sonucunda, Genel Müdür ve Yönetim Kurulu düşmüş ve TRT'de belirli bir süre yönetim krizi yaşanmıştır. TRT'nin, yapısal olarak özerk, tarafsız ve bağımsız bir organ olan RTÜK denetimine girdiğinde yaşadığı problemin, özerk olmayan bir dış denetleyici olan RTYK döneminde yaşanmamış olması dikkat çekicidir. $\mathrm{Bu}$ durum, denetimin niteliğini değerlendirirken, denetleyici kurumların yalnızca yapısal niteliklerine bakmanın yetersiz olduğunu göstermesi bakımından önem arz etmektedir. Zira bu kurumların bağlı olduğu mevzuat da son derece belirleyici olabilmektedir.

3984 sayılı Kanun'da 2002 yılında yapılan değişiklik ile TRT, RTÜK denetimi kapsamından çıkarılmış ve yayın denetimi bakımından, yalnızca kurum içi hiyerarşik denetimin uygulandığı 1983 yılı öncesine dönmüştür. 2011 yılında ise Avrupa Birliği’ne uyum kapsamında yayıncılık alanını düzenlemek amacıyla 6112 sayılı Kanun çıkarılmış ve 3984 sayılı Kanun ilga edilmiştir. Yeni Kanun, TRT'yi yeniden RTÜK denetimi kapsamına dahil etmiştir. Bu dönemdeki temel sorun ise; 3984 sayılı Kanun'da mevcut olan eşitsizliğin bu sefer TRT lehine dönmüş olmasıdır. Zira Kanun kapsamında, özel yayıncılar için para cezası, program durdurma, yayın durdurma ve lisans iptali gibi oldukça ağır yaptırımlar öngörülürken, TRT için yalnızca uyarı yaptırımı öngörülmüştür. 2013 yılından günümüze kadar geçen süre içerisinde TRT, 6112 sayılı Kanun'da öngörülen yayın hizmeti ilkelerini ve ticarî iletişimle ilgili hükümlerini 19 kez ihlâl etmesine rağmen, Üst Kurul tarafından yalnızca uyarılmıştır. Aynı ihlâlleri özel yayıncıların gerçekleştirmesi durumunda, onlara 
yüklü miktarda para cezaları ve/veya program durdurma yaptırımı uygulanacaktır. Bu durum, hukuktaki eşitlik ilkesine aykırılık arz etmektedir.

Sonuç olarak mevcut sorunu iki yolla çözmek mümkündür. İlki; TRT'nin güçlü bir kurum içi hiyerarşik denetime sahip olduğu varsayılarak, kurumun RTÜK yaptırımı dışında bırakılmasıdır. Böyle bir uygulama, aynı zamanda TRT denetçileri ile RTÜK denetçileri arasındaki yorum ve uygulama farklılıklarından doğan çelişkileri de ortadan kaldıracaktır. Diğer yol ise; kurum içi hiyerarşik denetimini gevşeterek, TRT'yi özel yayıncılarla 'mümkün olabildiğince' eşit statüde RTÜK denetimine tâbi tutmaktır. Böylece, TRT için de 'para cezası' ve 'program durdurma' gibi yaptırımlar uygulanabilecektir.

\section{Kaynaklar}

Akıncı, Müslüm (1999). Bağımsız İdarî Otoriteler ve Ombudsman, İstanbul: Beta Yayınevi.

Akkor Gül, Ayşen (2013). Görsel-İşitsel Politikasıyla Avrupa Birliği, İstanbul: Beta Yayınevi.

Cankaya, Özden (1997). Dünden Bugüne Radyo ve Televizyon, İstanbul: Beta Yayınevi.

Cankaya, Özden (2003). TRT Bir Kitle İletişim Kurumunun Tarihi: 1927-2000, İstanbul: Yapı Kredi Yayınları.

Cohen-Almagor, Raphael (2000). Liberal Democracy and the Limits of Tolerance, USA: The University of Michigan Press.

Coşkun, Sena (2018). Radyo ve Televizyon Yayın Hizmetlerinde Denetim, Ankara: Adalet Yayınevi.

Çapl1, Bülent (2001). Televizyon ve Siyasal Sistem, 2. Bask1, Ankara: İmge Kitabevi.

Çaplı, Bülent (2008). Fili Tarif Etmek, Ankara: İmge Kitabevi.

Erdoğan, İrfan (2003). Pozitivist Metodoloji, Ankara: Erk Yayınevi.

Giritli, İsmet, Bilgen, Pertev ve Akgüner, Tayfun (2006). İdare Hukuku Dersleri, İstanbul: Der Yayınları.

Gölcüklü, Feyyaz (1970). Haberleşme Hukuku, Ankara: A.Ü. Siyasal Bilgiler Fakültesi BYYO Yayını No: 1.

Gözler, Kemal ve Kaplan Gürsel (2011). İdare Hukukuna Giriş, 14. Bask1, Bursa: Ekin Yayınları.

Gözübüyük, Şeref (2008). Yönetim Hukuku, 27. Bask1, Ankara: Turhan Kitabevi.

Hilmes, Michelle (2011). Only Connect: A Cultural History of Broadcasting in the United States, 3rd Edition, Boston: Wadsworth. 
İçel, Kayıhan ve Ünver, Yener (2018). Kitle İletişim Hukuku, 13. Baskı, İstanbul: Beta Yayınevi.

Kaya, Reşit (2009). İktidar Yumağı, Ankara: İmge Kitabevi.

Kayış, Sedat Nuri (2006). Ben RTÜK Başkanıyken..., İstanbul: Remzi Kitabevi. Kitabevi.

Kejanlığlu, D. Beybin (2004). Türkiye'de Medyanın Dönüşümü, Ankara: İmge

Kocabaşoğlu, Uygur (2010). Şirket Telsizinden Devlet Radyosuna, İstanbul: İletişim Yayınları.

Mutlu, Erol (1998). İletişim Sözlügü, 3. Baskı, Ankara: Bilim ve Sanat Yayınları.

Odyakmaz, Zehra, Kaymak, Ümit ve Ercan, İsmail (2011). Anayasa Hukuku-İdare Hukuku, 13. Baskı, İstanbul: On İki Levha Yayınları. Yayınları.

Özçetin, Burak (2019). Kitle İletişim Kuramları, 3. Baskı, İstanbul: İletişim

Procedures for the consideration of sanctions for breaches of content standards on BBC broadcasting services and BBC on demand programme services, 03.04.2017. ofcom.org.uk, Erişim Tarihi: 19.08.2021.

Rawls, John (2020). Bir Adalet Teorisi, 3. Baskı, Çev: Vedat Ahsen Çoşar, Ankara: Phoenix Yayınevi.

RTÜK’ten TRT'ye 'sigara' cezas1, 28 Şubat 2010. https://www.cumhuriyet.com.tr/ haber/rtukten-trtye-sigara-cezasi-123294, Erişim Tarihi: 19.08.2021.

Salgın televizyona ve haber kanallarına ilgiyi artırdı, 21 Kasım 2020. https:// www.trthaber.com/haber/gundem/salgin-televizyona-ve-haber-kanallarina-ilgiyiartirdi-532854.html, Erişim Tarihi: 16.08.2021.

Serim, Ömer (2007). Türk Televizyon Tarihi 1952-2006, İstanbul: Epilson Yayınları.

Siebert, Fred S., Peterson, Theodere ve Schramm, Wilbur (1984). Four Theories of the Press, Urbana and Chicago: University of Illinois Press.

Tekinalp, Şermin (2003). Camera Obscura'dan Synopticon'a Radyo ve Televizyon, İstanbul: Der Yayınları.

Ulusoy, Ali (2003). Bağımsız İdarî Otoriteler, Ankara: Turhan Kitabevi.

Üst Kurul Kararları, 17 Ağustos 2021. https://www.rtuk.gov.tr/ust-kurul-kararlari, Erişim Tarihi: 18.08.2021.

Vural, Sacide (1994). Kitle İletişiminde Denetim Stratejileri, Ankara: Bilim Yayınları.

Destekleyen Kurum/Kuruluşlar: Herhangi bir kurum/kuruluştan destek alınmamıştır.

Çıkar Çatışması: Herhangi bir çıkar çatışması bulunmamaktadır. 